\title{
The Difficulties Preventing the Application of Activity Based Cost System from the Standpoint of Industrial Companies Operating In Allahabad City - India
}

\author{
Mr. Shaban E. A. Salem ${ }^{1}$, Dr. Shabana Mazhar ${ }^{2}$ \\ ${ }^{1}$ (Ph.D. Research Scholar, Business Administration Department, Joseph School of Business Studies, SHIATS, \\ India) \\ 2 (Associate Professor, Business Administration Department, Joseph School of Business Studies, SHIATS, India)
}

\begin{abstract}
This study aims to identifying the difficulties hindering the application of ABC system in companies operating in Allahabad-India. In order to achieve such aims, a questionnaire was developed and distributed to the population of study. SPSS program was used in the analysis.

The study concluded with some results. The most apparent is that the difficulties hindering the application of $A B C$ system in these companies are the difficulty of the division of business undertaken by the company to the activities of clear and specific, the lack of scientific qualifications and professional capable of implementing $A B C$ system, increasing the cost of application of $A B C$ system compared to the benefits expected from it is an impediment in the face of the application of the system in the company and the company does not keep pace with modern manufacturing environment.

The study recommends the companies should start gradually in the application of ABC system, also must these companies that are working to overcome the difficulties impeding the application of ABC system in these companies.
\end{abstract}

Keywords: ABC System, Traditional Cost System, Indirect Costs.

\section{Introduction}

The present modern industrial environment has changed and developed due to complex of production process and multiplicity of products by the company also bring machine instead human, this development led to a change in the cost structure, where led to increase the percentage of indirect costs. Indirect costs are those costs which cannot be identified with, or traced to a single product because they are incurred for several products (Jawahar Lal, 2009), where in the most of industries represented more than $40 \%$ of the total costs. In shade of this, the traditional cost system is unable to stand to calculate of these costs accurately, which results in of product cost distortion occurs due to allocating indirect costs to the products arbitrarily on the basis of direct labor hours used by each product and this lead to wrong cost information (Harsh, 1993).

The solution to the product cost distortion problem is activity based cost system which known as $\mathrm{ABC}$ system. ABC system provides the information to identify the components of indirect costs more precisely such that product design, development, production, and distribution decisions are better grounded. ABC system assigns resource costs to products more accurately, and as a result it acts as a decision support tool for companies. Decisions are not arbitrary, which is the case in traditional accounting systems, but based on facts (Johnson, et al, 1987). Therefore, ABC system is an approach for allocation of indirect costs.

Despite the importance of the application of $\mathrm{ABC}$ system in the companies because of its advantages there are many difficulties that hinder its application and these difficulties vary from one company to another. The study attempts to explain the concept of $\mathrm{ABC}$ system, reasons of emergence of $\mathrm{ABC}$ system and constituents of $\mathrm{ABC}$ systems.

\section{The Study Problem}

In light of the continuous rise of the percentage of indirect costs due to the use of modern technologies in manufacturing and the change in the manufacturing environment, $\mathrm{ABC}$ system came for treatment the shortcomings of traditional cost system in dealings with these costs. The study problem attempts to answer the following question: Are there any difficulties preventing the application of $\mathrm{ABC}$ in companies?

\section{The Study Objectives}

This study aims to attain the following objectives:

- To highlight the concept of $\mathrm{ABC}$ system, reasons of emergence of $\mathrm{ABC}$ system and constituents of $\mathrm{ABC}$ system.

- To determine the difficulties hindering the application of $\mathrm{ABC}$ system in companies. 


\section{Literature Review}

$\mathrm{ABC}$ system has gradually become a very popular concept that is being adopted across the globe .Since 1984 ABC gained attention and spread. Today ABC systems are widely used in USA, England and Germany. In India activity-based costing systems are still rarely used by companies.

Partridge, M. P (1994) This study stated that the most important reasons why U.S. companies are moving towards the application of the $\mathrm{ABC}$ system and abandon traditional systems is that $\mathrm{ABC}$ system leads to provide accurate data of products cost and to increase the competitiveness of these companies. This study also found that $29 \%$ of U.S. companies have tended towards the application of the ABC system instead of the traditional cost system, and that $56 \%$ of U.S. companies use the $\mathrm{ABC}$ system as an analytical tool and control in addition to their traditional systems.

Hicks Douglas (1999) this study showed that it is no longer the notion that the size of the project is important, and that the $\mathrm{ABC}$ system does not require a huge effort for the application, and it is effective and appropriate for any size business and the study also noted that small and medium-sized enterprises can be developed $\mathrm{ABC}$ system which does not require a large commitment of time or financial resources.

According to Johnson $T$ (1992) the objective of using the ABC system and analysis of costs is to improve the quality of accounting information to take sound decisions and the development of the $\mathrm{ABC}$ system has reached to stage attention of consumers to achieve better profits and competitiveness.

Raffish Norm (1991) in his study indicated that the ABC system helps to link between costs and products based on sources that have been consumed in the activities required to get the products and identify opportunities to improve costs which do not contain added value.

As per Pattison Diane and Arendt Carrie (1994) the ABC system does not fit with all companies, it must be the company in a competitive and in need continuing to reduce costs. Also this study concluded that the management of the company which applied this system must have to involve employees in the company in the decision-making process and design.

Waeytens Dominique and Bruggeman Werner (1994) in their paper "Barriers to Successful Implementation of $\mathrm{ABC}$ for Continuous Improvement" stated that $\mathrm{ABC}$ system is the right tool to streamline and guide the process of continuous improvement through the use of activity-based management.

Ittner, C. Lanen, W. and Larcker, D (2002) this study aimed to demonstrate the link between the $\mathrm{ABC}$ system and manufacturing performance, where applied this study on 2789 factories in the United States of America. This study found that the reason for the widespread use of the ABC system was due to the high levels of quality and a drop in industrial costs when you use this system.

\section{Concept of ABC System and Reasons of its Emergence.}

Cooper and Kaplan has presented ABC system project in the $1980_{\mathrm{s}}$ as an alternative to be more suitable to the allocation of indirect costs to end products than the traditional cost system, it aims to rectify the problem of inaccurate cost information due to selection of wrong bases of indirect cost apportionment. In the words of Cooper and Kaplan, $\mathrm{ABC}$ system calculate the costs of individual activities and assign costs to cost objects such as products and services on the basis of activities undertaken to produce each product and service.

According to C.I.M.A., London, $\mathrm{ABC}$ system is: Cost attribution to cost units on the basis of benefits received from indirect activities, i.e., ordering, setting up, assuring quality, etc (Arora, 2013). ABC system is that costing in which costs are first traced to activities and then to products, $\mathrm{ABC}$ is costing system which focuses on activities performed to produce products (Jawahar Lal , 2009).

The logic behind $\mathrm{ABC}$ system is products consume activities and activities consume resources. The relationships between activities and products have been shown as follows:

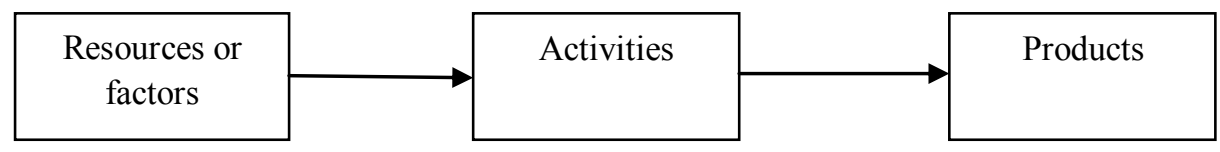

Fig 1: ABC System Process.

Can be summarized the most important reasons that helped the emergence of $\mathrm{ABC}$ as follows (Horngren, et al, 2006):

- Increase the variety of products so as to meet the demands of different customers.

- The high proportion of indirect costs due to development of production processes.

- Progress of information technology.

- Increased competition in products markets.

All this has led to the need for a new tool to allocate indirect costs on activities and then on product units. 


\section{Constituents of ABC System.}

The application of $\mathrm{ABC}$ system is a complex process that requires many of the experiences and exhausted a lot of resources of the organization so the administration must make sure in advance of the expected benefits are greater than the costs of the application system. This can be considered the following circumstances and conditions encouraging for the application of the system, but it may become necessary with the availability of these circumstances:

- Management's belief that the traditional cost systems prevailing have, which are based on direct labour costs distort the cost of the product or service.

- Change in the modern industrial environment in terms of the increasing use of advanced manufacturing systems in production processes which led to the reduction of direct labor cost of the total cost of the product, the higher the proportion of indirect costs of the total product cost.

- The multiplicity and diversity of products with different sizes, making the production process is complex.

- Availability the accounting systems be able to provide accurate data and information and at the lowest cost in order to identify and measure the relationship between cost and their causes.

- The increasing use of supporting activities at the organization such as the engineering design of the product, design production processes, programming, marketing, accounting, and automated processing of information, etc.

- The difficulty of determining the cost of certain products or services, and then the difficulty of interpreting the profitability of certain products.

- Lower prices for competing products or services in the market, and the loss of many of the tenders without understanding the reasons for it.

- Low of useful life of the product, which requires the exclusion of certain products and the development and introduction of new products and in line with the expectations of current and future customers.

- Increasing competition locally and globally so that it becomes reduce costs a strategy for continuing the organization and maintaining its market share.

\section{Nature of Data}

\section{Study Methodology}

The data required for the study has been collected from secondary sources by relying on the scientific books, published papers and researches.

\section{Data Collection Method}

The present study has been adopted on the comprehensive survey of the population of the study which consists of entire the industrial companies operating in Allahabad - India, whether they government or private and large or medium companies. The population of study consists of $\mathbf{1 8}$ companies.

To gather data a questionnaire had been designed and distributed on the population of study a questionnaire for each company. The questionnaire includes a set of questions with aim to explore the views of the industrial companies about the difficulties hindering the application of $\mathrm{ABC}$ system in these companies.

\section{Findings/Discussions}

The study data has been analyzed by using SPSS program (Statistical Packing for Social Sciences) and the following table showed the results:

\section{Table 1: Frequency Distribution and Percentages of the Responses of the Study Participants about the} Difficulties of Application of ABC System in Companies.

\begin{tabular}{|c|c|c|c|c|c|c|c|}
\hline \multirow[t]{2}{*}{ No } & \multirow[t]{2}{*}{ Questions } & Percentage $\%$ & \multirow{2}{*}{$\begin{array}{c}\text { Strongly } \\
\text { agree }\end{array}$} & \multirow[t]{2}{*}{ Agree } & \multirow[t]{2}{*}{ Neutral } & \multirow[t]{2}{*}{ Disagree } & \multirow{2}{*}{$\begin{array}{l}\text { Strongly } \\
\text { disagree }\end{array}$} \\
\hline & & Number & & & & & \\
\hline \multirow[t]{2}{*}{1} & \multirow[t]{2}{*}{ There is no costs system in the company } & Number & 2 & 4 & 3 & 3 & 6 \\
\hline & & Percentage $\%$ & $11.1 \%$ & $22.2 \%$ & $16.7 \%$ & $16.7 \%$ & $33.3 \%$ \\
\hline \multirow[t]{2}{*}{2} & \multirow{2}{*}{$\begin{array}{l}\text { Lack of understanding and conviction of } \\
\text { administration the importance of the } \\
\text { application of the ABC system }\end{array}$} & Number & 3 & 4 & 4 & 4 & 3 \\
\hline & & Percentage\% & $16.7 \%$ & $22.2 \%$ & $22.2 \%$ & $22.2 \%$ & $16.7 \%$ \\
\hline \multirow[t]{2}{*}{3} & \multirow{2}{*}{$\begin{array}{l}\text { The administrative structure of the } \\
\text { company does not help much in the } \\
\text { success of the ABC system }\end{array}$} & Number & 1 & 3 & 7 & 4 & 3 \\
\hline & & Percentage $\%$ & $5.6 \%$ & $16.7 \%$ & $38.9 \%$ & 22.2 & $16.7 \%$ \\
\hline \multirow[t]{2}{*}{4} & \multirow{2}{*}{$\begin{array}{l}\text { The difficulty of the division of business } \\
\text { undertaken by the company to the }\end{array}$} & Number & 3 & 4 & 8 & 1 & 2 \\
\hline & & Percentage\% & $16.7 \%$ & $22.2 \%$ & $44.4 \%$ & $5.6 \%$ & $11.1 \%$ \\
\hline
\end{tabular}


The Difficulties Preventing the Application of Activity Based Cost System from the Standpoint ....

\begin{tabular}{|c|c|c|c|c|c|c|c|}
\hline & activities of clear and specific & & & & & & \\
\hline \multirow[t]{2}{*}{5} & \multirow{2}{*}{$\begin{array}{l}\text { The lack of scientific qualifications and } \\
\text { professional capable of implementation } \\
\text { ABC system }\end{array}$} & Number & 6 & 4 & 4 & 2 & 2 \\
\hline & & $\begin{array}{c}\text { Percentage } \\
\%\end{array}$ & $33.3 \%$ & $22.2 \%$ & $22.2 \%$ & $11.1 \%$ & $11.1 \%$ \\
\hline \multirow[t]{2}{*}{6} & \multirow[b]{2}{*}{$\begin{array}{l}\text { Increasing the cost of application of } \\
\text { ABC system compared to the benefits } \\
\text { expected from it is an impediment in the } \\
\text { face of the application of the system in } \\
\text { the company }\end{array}$} & Number & 5 & 5 & 3 & 2 & 3 \\
\hline & & Percentage $\%$ & $27.8 \%$ & $27.8 \%$ & $16.7 \%$ & $11.1 \%$ & $16.7 \%$ \\
\hline \multirow[t]{2}{*}{7} & \multirow{2}{*}{$\begin{array}{l}\text { The company does not keep pace with } \\
\text { modern manufacturing environment } \\
\text { it is an impediment in the face of the } \\
\text { application of the system in } \mathrm{ABC} \\
\text { company }\end{array}$} & Number & 4 & 4 & 2 & 6 & 2 \\
\hline & & Percentage & $22.2 \%$ & 22.2 & $11.1 \%$ & $33.3 \%$ & $11.1 \%$ \\
\hline
\end{tabular}

\section{The previous table shows the following results:}

- $\quad$ That $33.3 \%$ of the companies surveyed said that there is no cost system in the companies, while $50 \%$ of these companies said that there is cost system in the companies, also we note that $16.7 \%$ of these companies in the neutral category.

- That $38.9 \%$ of the companies surveyed think that there is lack of understanding and conviction from the administration the importance of the application of the $\mathrm{ABC}$ system, while the same percentage of these companies think that there is understanding and conviction from the administration the importance of the application of the $\mathrm{ABC}$ system, also the results show that $22.2 \%$ of these companies in the neutral category.

- $\quad$ That $22.3 \%$ of the companies surveyed see that the administrative structure of the companies do not help much in the success of the ABC system, while $38.9 \%$ of these companies see that the administrative structure of these companies help in the success of the ABC system, also we can note that $38.9 \%$ of these companies in the neutral category.

- $\quad$ That $38.9 \%$ of the companies surveyed said that there is difficulty in division of business undertaken by the company to activities be clear and specific, while $16.7 \%$ of these companies said that there is no is difficulty in division of business undertaken by the company to activities be clear and specific, also the results show that $44.4 \%$ of these companies in the neutral category.

- That $55.5 \%$ of the companies surveyed think that the lack of scientific qualifications and professional capable of implementation ABC system, while $22.2 \%$ of these companies do not think that, also we can note that $22.2 \%$ of these companies in the neutral category.

- That $55.6 \%$ of the companies surveyed see that increasing the cost of application of ABC system compared to the benefits expected from it is an impediment in the face of the application of the system in the company, while $27.8 \%$ of these companies do not see that, also we can see that $16.7 \%$ of these companies in the neutral category.

- $\quad$ That $44.4 \%$ of the companies surveyed said that the company does not keep pace with modern manufacturing environment it is an impediment in the face of the application of ABC system in the company, while $50 \%$ of these companies said that the company keep pace with modern manufacturing environment it is not an impediment in the face of the application of the ABC system in the company, also we can see that $11.1 \%$ of these companies in the neutral category.

The following table shows the mean of the questions related the difficulties of application of $\mathrm{ABC}$ system in companies.

Table 2: Mean of the Responses of the Study Participants about the Difficulties of Application of ABC System in Companies

\begin{tabular}{|l|l|c|}
\hline \multicolumn{1}{|c|}{ No } & \multicolumn{1}{|c|}{ Questions } & Mean \\
\hline $\mathbf{1}$ & There is no costs system in the company & 2.61 \\
\hline $\mathbf{2}$ & $\begin{array}{l}\text { Lack of understanding and conviction of administration the importance of the } \\
\text { application of the ABC system }\end{array}$ & 3 \\
\hline $\mathbf{3}$ & $\begin{array}{l}\text { The administrative structure of the company does not help much in the success of } \\
\text { the ABC system } \\
\text { The difficulty of the division of business undertaken by the company to the } \\
\text { activities of clear and specific }\end{array}$ & $\mathbf{3 . 2 8}$ \\
\hline $\mathbf{5}$ & $\begin{array}{l}\text { The lack of scientific qualifications and professional capable of implementation } \\
\text { ABC system }\end{array}$ & $\mathbf{3 . 5 6}$ \\
\hline $\mathbf{6}$ & Increasing the cost of application of ABC system compared to the benefits & $\mathbf{3 . 3 9}$ \\
\hline
\end{tabular}




\begin{tabular}{|c|c|c|}
\hline & $\begin{array}{l}\text { expected from it is an impediment in the face of the application of the system in } \\
\text { the company }\end{array}$ & \\
\hline 7 & $\begin{array}{l}\text { the company does not keep pace with modern manufacturing environment } \\
\text { it is an impediment in the face of the application of the system in the company }\end{array}$ & 3.11 \\
\hline
\end{tabular}

From the above table it is that clear the mean is relatively high on some of the difficulties such as the difficulty of the division of business undertaken by the company to the activities of clear and specific, the lack of scientific qualifications and professional capable of implementing $\mathrm{ABC}$ system, increasing the cost of application of $\mathrm{ABC}$ system compared to the benefits expected from it is an impediment in the face of the application of the system in the company and the company does not keep pace with modern manufacturing environment, while considered the difficulties low in category of disagree such as there is no costs system in the company and the administrative structure of the company does not help much in the success of the ABC system.

\section{Conclusions}

Based on the study of participant answers to the inquiry and after analyzing the study data, the study had reached the following conclusions:

- Activity based cost system is an alternative to traditional way of indirect cost accounting.

- The underlying philosophy of Activity based cost system is that products consume the activities and activities consume the resources.

- Activity based cost system brings accuracy and reliability in product cost determination by focussing on cause and effect relationship in the cost incurrence.

- There are difficulties hindering the application of $A B C$ system in these companies such as the difficulty of the division of business undertaken by the company to the activities of clear and specific, the lack of scientific qualifications and professional capable of implementing $\mathrm{ABC}$ system, increasing the cost of application of $\mathrm{ABC}$ system compared to the benefits expected from it is an impediment in the face of the application of the system in the company and the company does not keep pace with modern manufacturing environment.

\section{Recommendations}

- The companies should gradually start applying the ABC system.

- There is a need to convince the administration about benefits and importance of the application of $\mathrm{ABC}$ system .

- Companies must overcome all difficulties impeding the application of the $\mathrm{ABC}$ system.

- The companies must organize training programs for accountants from both practical and professional side, also these companies must use computer in processing all their operations.

\section{References}

[1]. Cooper, R. \& Kaplan, R. (1998). Cost Cutting Activity. Economist, 61, 57-67.

[2]. Harsh, Mary Frances. (1993). The Impact of Activity Based Costing on Managerial Decisions: An Empirical Analysis (Unpublished doctoral thesis). Virginia Polytechnic Institute \& State University, Blacksburg, VA, USA.

[3]. Hicks Douglas, T. (1999). Yes, ABC for Small Business Too Journal of accountancy. Issue: 2, 41, 40-51.

[4]. Horngren, C, Datar, S. \& Foster, G. (2006). Cost Accounting (A Managerial Emphasis) 12 ${ }^{\text {th }}$ Ed. New Jersey: Prentice Hall International.

[5]. Ittner, C. Lanen, W. \& Larcker, D. (2002). The Association Between Activity-Based Costing and Manufacturing Performance. Journal of Accounting Research, 116, 111-130.

[6]. Jawahar Lal. (2009). Cost Accounting. New Delhi: Tata McGaw-Hill Publishing.

[7]. Johnson, H. T. \& Robert S. Kaplan. (1987). Relevance Lost: The Rise and Fall of Management Accounting. Boston: Harvard Business School Press.

[8]. Johnson, T. (1992). It's Time to Stop Overselling Activity-Based Concepts. Management Accounting, 28, $26-35$.

[9]. M. N. Arora. (2013). Cost Accounting. New Delhi: Vikas Publishing House PVT Ltd.

[10]. Partridge, M. P. (1994). More Companies Turn To ABC. Journal of Accounting, 6, 4-14.

[11]. Pattison, Diane \& Arendt, Carrie. (1994). Activity-Based Costing it Doesn't Work All the Time. Management Accounting, 57, 5561.

[12]. Raffish, N. \& P. Turney. (1991). The CAM-I Glossary of Activity-Based Management. Arlington: CAM-I.

[13]. Waeytens, Dominique \& Bruggeman, Werner. (1994). Barriers to Successful Implementation of ABC for Continuous Improvement. International Journal- of Production-Economics, 47, 39-52. 